\title{
SIX SIGMA TRAINING FOR LECTURER AND STUDENT COLLEGE
}

\author{
Hasbullah, Jakfat Haekal, Sawarni Hasibuan \\ Universitas Mercu Buana Jakarta, Indonesia.
}

\begin{abstract}
Six Sigma is a management tool that is focused on quality control by exploring the overall work operating system that has the aim of eliminating production defects, maximum work results, best service, process without maintenance and time efficiency to minimize costs. Six Siga is comprehensive, which means strategies, disciplines, and tools to achieve and support the success of the business and its operations. Six Sigma is called a strategy because it is focused on increasing customer satisfaction, called a discipline because it follows the formal model, namely DMAIC (Define, Measure, Analyze, Improve, Control). Six Sigma is widely proven in practice and research shows high success in its application in various corporate organizations, hospitals, education, factories, airlines and universities. Universities need to contribute in improving the quality of lecturers and students in producing excellent quality performance. Each individual student and lecturer is required to produce excellent quality in serving his work, both on campus, work units and the community. One method used to provide solutions to improve organizational internal process standards that aims to minimize mismatches in work processes and results is the Six Sigma method. Six Sigma training activities by Six Sigma certified trainers are conducted at the Bina Tunggal Bekasi STT community which is a tertiary institution ranked and under the Mercu Buana University. Incidentally, the two institutions have a partnership that has been fostered so far.
\end{abstract}

Keywords: Six Sigma, DMAIC, SMEs

\section{INTRODUCTION}

Six Sigma is a quality control strategy that was first coined by Motorola. by exploring the overall work operating system that has the aim to eliminate production defects, get work results without defects, perfect service, efficient processes and optimal time. Six Sigma cannot be claimed as an ordinary discipline or management strategy. Six Sigma consists of methods from various disciplines and becomes a tool to achieve and support the success of the business and its operations. Six Sigma focuses on increasing customer satisfaction, which has an obsession with flawless output. Six Sigma is called a discipline because it follows the formal model namely; DMAIC (Define, Measure, Analyze, Improve, Control). Six Sigma is widely proven in practice and research shows high success in its application in various corporate organizations, hospitals, education, factories, airlines and universities.

Mercu Buana University is determined to improve the quality of lecturers and students in the aspects of competency, quality of performance and work operations. It is expected that each individual student and lecturer is required to produce work of excellent quality in serving his work, both on campus, work units and the community. It also needs to be instilled in various institutions, universities and various organizations that are partners and fostered by Mercu Buana University. One method used to provide solutions to improve organizational internal process standards that aims to minimize mismatches in work processes and results is the Six Sigma method. Six Sigma training activities by Six Sigma certified trainers are conducted at the Bina Tunggal Bekasi STT community which is a tertiary institution ranked and under the Mercu Buana University. Incidentally, the two institutions have a partnership that has been fostered so far.

Situation analysis shows that training needs to be done in providing knowledge and understanding in six sigma and its benefits. The training aims to have participants understand the substance of how to apply six sigma to their work units.

Based on field observations and preliminary survey, it formulated the problem of how to formulate a six sigma training method so as to provide an understanding and knowledge in the implement it so as to produce output (output) work to have excellent quality. 


\section{METHODS}

The priority targets of the target audience are researchers, lecturers, students and outside participants around the Bina Tunggal College of Technology and Mercu Buana University. This activity is packaged simply, expected to be interesting and enthusiastically followed by researchers and lecturers.

The types of activities that will be carried out effectively are as follows:

1. Varied Lectures and Discussion Questions and Answers

This method was chosen to convey the basic concepts in increasing knowledge, skills and impact to understand how to understand Six Sigma and its application. Use of this method with the consideration that the lecture method combined with audio and video can provide material that is relatively easy to understand, compact, fast and easy with speakers who have a Six Sigma certificate.

2. Training and Discussion of Questions and Answers

This Six Sigma training will provide a special forum for discussion and question and answer.

3. Practice and Practice

This method is used to provide an opportunity for each participant to conduct a quality condition analysis and six sigma practice simulation.

\section{DISCUSION AND RESULT}

The six sigma project aimed to improve the use and reliability of self-issue and in doing so number of resolutions were prescribed based on the facts which emerged through the six sigma process. Six sigma was valuable in that it focused attention on what the problem was instead of assumptions about what the problem might be. In this way time and resources were aimed at fixing what was actually wrong instead of being used randomly. The charter outlined the fundamental problem and the aim of the project and provided a framework in which to work.

This way everyone was clear about what they were working towards, and because the project time was short, it meant costs in terms of staff time and resources were kept low. The process of six sigma is very structured with its series of phases and the tools applied throughout the process. This meant that the team concentrated on the specific task at each given stage and did not get misled by additional data which may have had nothing to do with the task at hand.

The process built on a TQ ethos in the university and there was a commitment both from STT Bina Tunggal to tackle the problem. Had the project indicated that it was not possible to increase self-issue levels then at least the STT Bina Tunggal would have known that it had done all that it could.

The six sigma project suggested a formal fault reporting system be put in place for STT Bina tunggal to help to control the length of time a unit was out of order. It would also help to reduce the number of times faults occurred lecturer would bevable to analyse faults from the log report and determine if work needed to be carried out on the units before it became a major problem. together the key people who were able to help tackle the problem. STT Bina Tunggal benefited

\section{REFERENCES}

Aflaki, A., Mirnezhad, M., Ghaffarianhoseini, A., Ghaffarianhoseini, A., Omrany, H., Wang, Z. H., \& Akbari, H. (2017). Urban heat island mitigation strategies: A state-of-the-art review on Kuala Lumpur, Singapore and Hong Kong. Cities, 62, 131-145.

Gaspers, Vincent, ’Lean Six Sigma for Manufacturing and Service Industri”, Gramedia, Jakarta, Tahun 2007.

Dolcemascolo, Darren, "Improving The Extended Value Stream: Lean For The Entire Supply", Productivity Press, hal. 35 - 37, New York, Tahun 2006.

Feld, William M., "Lean Manufacturing: Tools, Techniques, and How To Use Them, vol. 2" St. Lucie Press, Boca Raton - Florida, Tahun 2000. [4] Pyzdek, Thomas, “The Six Sigma Project Planner: A Step by Step Guide to Leading a Six Sigma Project Trough DMAIC”, McGraw-Hill, New York, Tahun 2003.

Mikel J. Harry Richard Schroeder Don R. Linsenmann Richard Schroeder "Six Sigma: The Breakthrough Management Strategy Revolutionizing The World's Top Corporations.”, Bantam Doubleday Dell Pub, Tahun 2000 
Ming-Hui, W. A. N. G., ZHANG, K. J., Qin-Lan, G. U., Xiao-Ling, B., \& Jin-Xin, W. (2017). Pharmacology of mangostins and their derivatives: A comprehensive review. Chinese journal of natural medicines, 15(2), 81-93.

Chandio, I. A., Matori, A. N. B., WanYusof, K. B., Talpur, M. A. H., Balogun, A. L., \& Lawal, D. U. (2013). GIS-based analytic hierarchy process as a multicriteria decision analysis instrument: a review. Arabian Journal of Geosciences, 6(8), 3059-3066.

Istadi, I. (2015, December). Strategi Pengembangan dan Indeksasi Jurnal Bereputasi Internasional. In Makalah Workshop Pengelolaan Jurnal cecara Elektronik Menuju Indeksasi Internasional (Vol. 3).

Arsyad, S. (2014). Menulis Artikel Jurnal Internasional dengan gaya retorika Bahasa Inggris.

Wekke, I. S. (2015). Teknik penulisan artikel untuk jurnal dengan indeks Scopus. 